\title{
Effects of Prolactin and Growth Hormone on Growth and Metamorphosis of Tadpoles of the Frog, Rana pipiens ${ }^{1}$
}

\author{
PATRICIA S. BROWN2 AND B. E. FRYE \\ The University of Michigan, Department of Zoology, Ann Arbor, Michigan
}

Received August 7, 1968

\begin{abstract}
Mammalian prolactin at doses of 1-50 $\mu \mathrm{g}$ /day promoted growth (increased wet weight, dry weight and body length) in Rana pipiens tadpoles. Mammalian growth hormone (GH) promoted growth only at the higher doses ( $50 \mu \mathrm{g} /$ day and above) and was not so effective as prolactin.

Prolactin also inhibited metamorphosis (at doses of $5 \mu \mathrm{g} /$ day and above). Inhibition of metamorphosis did not appear to be due to reduction in tissue sensitivity to thyroxine since prolactin-treated tadpoles metamorphosed in response to exogenously administered thyroxine (4-100 $\mu \mathrm{g} /$ /iter) to the same extent as controls. Prolactin promoted further growth in tadpoles in which the thyroid level had been reduced with thiouracil or by thyroidectomy. This indicates that growth promotion caused by prolactin is not just the result of thyroid inhibition, although it is possible that a portion of the growth stimulation is due to the antithyroid action of prolactin.
\end{abstract}

The pituitary gland of amphibians has been thought to be necessary for normal growth in anuran tadpoles since the early work of Allen (1916) and Smith (1916) with hypophysectomized tadpoles. The suggestion that prolactin may be the pituitary hormone necessary for normal growth in amphibians is more recent (Etkin and Lehrer, 1960). Etkin and Lehrer found that $R$. pipiens tadpoles that had had their pituitary transplanted to the tail grew larger than control tadpoles, and suggested that the transplant might be releasing a growth factor in excess which was inhibited when the pituitary was in its normal location. Since mammalian pituitaries are known to

1 This work was supported in part by an American Cancer Society Institute Research Grant (IN-40-H), by a grant from the University of Michigan Cancer Research Institute and a summer NIH training grant (NIH-2TIGM939).

2 Present address: Department of Biological Sciences, State University of New York, Albany, New York 12203. This is part of a thesis submitted in partial fulfillment of the requirements for a Ph.D. degree in the Department of Zoology of the University of Michigan. release prolactin when removed from hypothalamic inhibition (Everett, 1966) they suggested that the factor producing excess growth in tadpoles bearing pituitary grafts might be prolactin.

Stimulated by the work of Etkin and Lehrer, Berman et al. (1964), Bern et al. (1967), Etkin and Gona (1967), and Rémy and Bounhiol (1965, 1966) found that treatment of anuran tadpoles with mammalian prolactin preparations stimulates growth. Growth hormone has also been reported to cause an increased growth in tadpoles (Bounhiol et al., 1959; Rémy, 1964; Rémy and Bounhiol, 1966; Etkin and Gona, 1967). Thus it appears that amphibian growth is sensitive to both growth hormone and prolactin rather than to only one or the other.

Recenty prolactin has been reported to inhibit metamorphosis as well as to promote growth in tadpoles (Etkin and Gona, 1967). Since growth is also stimulated concurrently with the inhibition of metamorphosis by other means, such as thyroidectomy or treatment with thyroid inhibitors (Allen, 1918; Hoskins and Hoskins, 1919; Steinmetz, 
$1952,1954)$, the possibility is raised that the growth effect of prolactin is secondary to the inhibition of metamorphosis.

In this study we have examined the relationship between the growth and metamorphosis effects of prolactin and growth hormone by attempting to determine whether or not the pituitary hormones can stimulate a further increase in growth in hypothyroid animals and whether or not prolactin alters tissue sensitivity to thyroxine. We have also examined the relative growth-promoting and metamorphosisinhibiting activities of prolactin and growth hormone in tadpoles.

\section{MATERIALS AND METHODS}

\section{Tadpoles}

Rana pipiens tadpoles were reared from eggs obtained by induced breeding, using the method of Wright and Flathers (1961). The adults used for the fertilizations were obtained from the Lemberger Company in Wisconsin and from C. H. Mumley, in Vermont. All of the tadpoles used in any one experiment were from the same fertilization. The tadpoles were reared at room temperature in shallow enamel pans $\left(12 \times 17 \times 2 \frac{1}{2} \mathrm{in}\right.$.) in aerated tap water or well water. They were fed cooked washed spinach. The tadpoles used in these experiments ranged initially in size from $2-5 \mathrm{~g}$ and $5-8 \mathrm{~cm}$, and in stage (Taylor and Kollros, 1946) from VIII-XVII. Tadpoles were sorted according to size and metamorphic stage so that animals in any one experiment were uniform. In order to keep individual records during an experiment, each animal was kept separately in a 4-in. finger bowl in approximately $200 \mathrm{ml}$ of water. They were fed and the bowls cleaned daily. The tadpoles were kept at temperatures between $20-23^{\circ}$ and on 10-14 $\mathrm{hr}$ of daylight. All of the groups in one experiment were subjected to identical light and temperature conditions.

Weight and length measurements were made every week in most experiments, and sometimes more frequently. Total body length including the tail was used for the length measure. The tadpoles were blotted on a damp towel prior to weighing. Hind leg length was measured in several experiments. State of metamorphosis was determined by the Taylor-Kollros (1946) series of metamorphic stages.

Injections were made intraperitoneally by inserting a 30-gauge syringe needle through the opercular opening and into the body cavity, ventral to the gut. In all of the experiments the volume of hormone solution or saline that each animal received was $0.01 \mathrm{ml}$ per injection.

Thyroidectomy of tadpoles was done using the method of Dent (1959) on tadpoles between stages VI and XIV. Tadpoles healed in approximately 1 week after surgery at which time their food consumption approached normal. In the control animals of experiments utilizing thyroidectomized tadpoles, the thyroid gland was surgically exposed but not removed.

Dry weight measurements were made on control and prolactin-treated tadpoles in one experiment. The tadpoles were dried in a vacuum oven and weighed at 24-hr intervals until the weights were constant.

\section{Hormones and Drugs}

The pituitary hormones used were National Institutes of Health (NIH) bovine prolactin (B-2; $19.9 \mathrm{IU} / \mathrm{mg}$ ), NIH bovine growth hornone (GH) (B-12;0.97 USP units/mg) and NIH porcine GH (1.6 units $/ \mathrm{mg})$. The hormone solutions were made up by dissolving the powdered hormone in saline made basic with dilute sodium hydroxide. The solution was subsequently brought to $\mathrm{pH} .8$ using dilute hydrochloric acid. The preparation was diluted to the desired concentration with $0.7 \%$ sodium chloride. The hormone solutions were made up every 4 days and kept at $4^{\circ}$ when not in use. Since the bovine GII preparation had a greater amount of thyrotropin (TSH) contamination (0.013 USP units/mg) than the prolactin preparation ( $<0.0002$ USP units $/ \mathrm{mg}$ ) it was desirable to do an experiment using a purer preparation of $\mathrm{GH}$. A porcine GH preparation which was thought to have an extremely low TSH contanination was oblained from Dr. A. E. Wilhelmi (NIH).

When thyroid hormone or thiouracil solutions were used, the tadpoles were immersed in the solutions. Both thyroid hormone and thiouracil solutions were made up by dissolving the powde: in a small amount of dilute sodium hydroxide solution. This was diluted to the appropriate concentration with either aerated tap water or well water and the $\mathrm{pH}$ was adjusted to approximately 7 with dilute hydrochloric acid. The animals in these solutions, like the corresponding control animals, were changed daily. The thyroid hormone used was 1-sodium thyroxine pentahydrate.

The tadpoles were anesthetized prior to surgery, injection or measurement with MS222 (tricaine methanesulphonate, Sandoz).

Statistical comparisons were made using small sample statistical method's (Student's $t$ test; Dunnett's tesi). As used in this paper a significant difference is indicated by a $p$ value of 0.05 or less. 


\section{RESULTS}

Effects of Prolactin and Growth Hormone on Intact Tadpoles

In order to determine the effects of various doses of prolactin and growth hormone on the body length and weight of intact tadpoles, nine groups of tadpoles were treated daily with various doses of prolactin and growth hormone. Weight and length changes for a 2-weck pcriod are shown in Fig. 1.

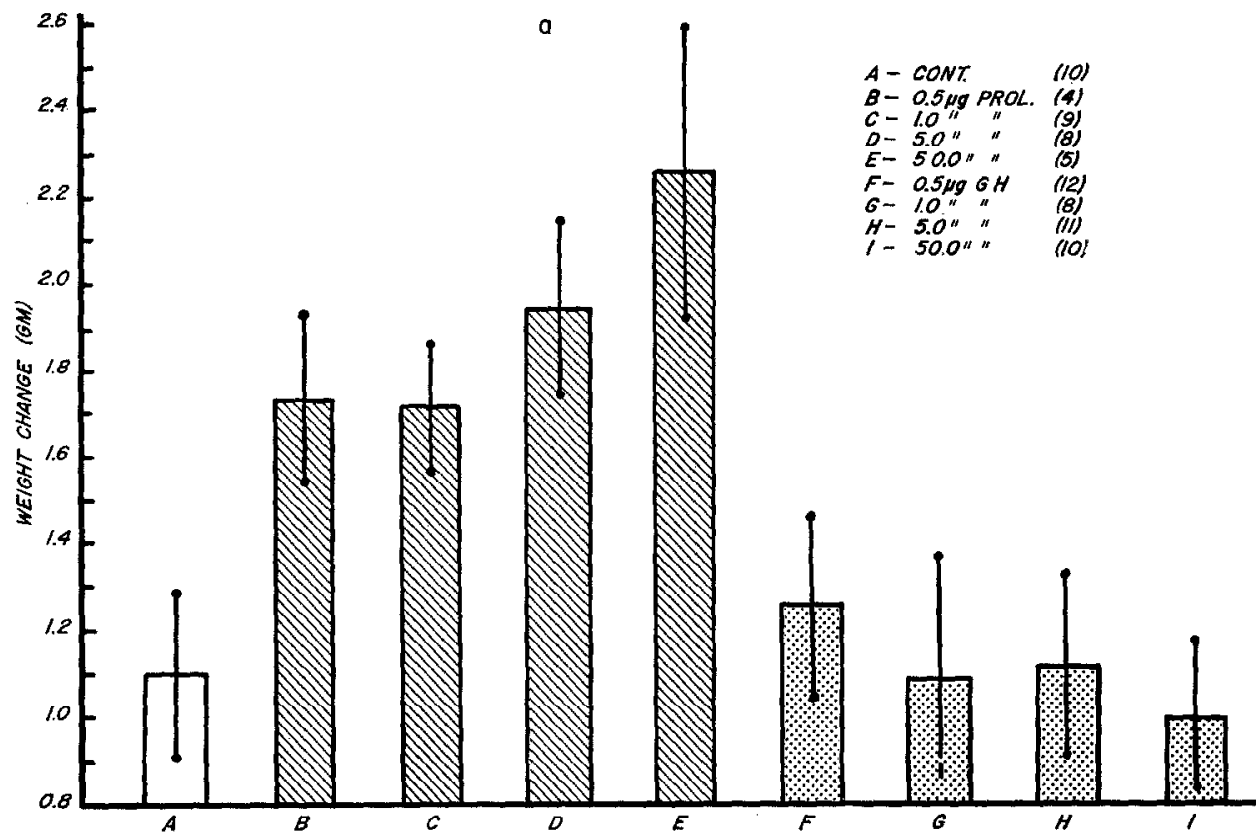

o

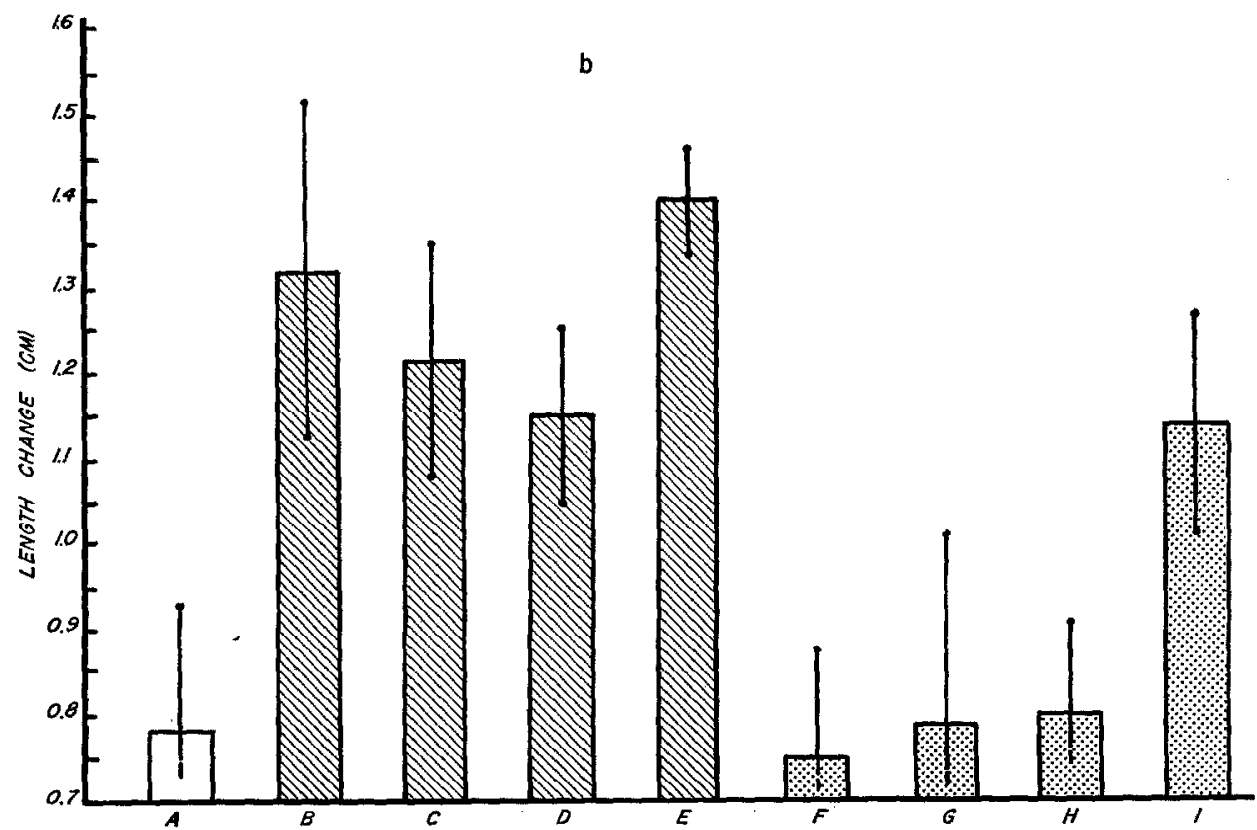

Frg. 1. Mean weight and length changes \pm standard errors in control, prolactin and GH-treated tadpules in 2 weeks. Numbers in parentheses indicate number of animals per group. 
TABLE 1

Weight and Length Changes in Tadpoles after 2-Weeks of Damy Treatmant of Saline, Growth Hormone, and Prolactix

$(\mathrm{P}=$ prolactin; $n=$ number of animals $)$

\begin{tabular}{|c|c|c|c|c|c|}
\hline \multirow[b]{2}{*}{ Group } & \multirow[b]{2}{*}{$n$} & \multirow[b]{2}{*}{ Treatment } & Wet wt. change (g) & Length change (om) & \multirow[b]{2}{*}{ Dry wt. $(\mathrm{g})$} \\
\hline & & & Mean $\pm S E$ & Nean $\pm S E$ & \\
\hline$A$ & 12 & Saline & $1.02 \pm .08$ & $1.20 \pm .06$ & .2212 \\
\hline$B$ & 11 & $50 \mu \mathrm{g} \mathrm{GH}$ & $1.21 \pm .08$ & $1.55^{* a} \pm .10$ & \\
\hline $\mathrm{C}$ & 12 & $10 \mu g \mathrm{P}$ & $1.58^{* a} \pm .09$ & $1.90^{* b} \pm .08$ & $2362^{* e}$ \\
\hline
\end{tabular}

* Significantly different from Group A (see text).

a $(p<.01)$.

${ }^{b}(p<.001)$.

$\cdot(p<.025)$.

Prolactin in doses of $1 \mu \mathrm{g} /$ day, or greater, produced significant increases in both weight and length. One-half microgram per day did not produce a significant effect on growth. A repeat of this experiment using the lower doses of prolactin $(0.5$ and $1.0 \mu \mathrm{g} /$ day $)$ gave similar results and confirms the minimum effective growth promoting dose of prolactin to be approximately $1 \mu \mathrm{g} /$ day when administered daily over a 2 -week period.

In a similar experiment, dry weight as well as wet weight and length were compared in tadpoles treated with saline and tadpoles treated with $10 \mu \mathrm{g} /$ day prolactin. The length and weight data substantiate those of the above experiments (Table 1). The dry weights were compared using the Wilcoxon signed rank test and control and prolactintreated animals differed significantly $(p<$ .025). The dry weight data indicate that the increased size promoted by prolartin is due to more than mere water uptake.

Growth hormone did not have a significant effect on either weight or length at any dose used in this experiment (Fig. 1) although at a dose of $50 \mu \mathrm{g} /$ day, the GH effect was just below the limits of significance, suggesting that it might be possible to demonstrate a GH effect on tadpole growth with larger groups of animals or longer treatments or both. When this experiment was repeated with a purified porcine GH preparation, $50 \mu \mathrm{g} /$ day for 2 weeks had no significant effect on weight, but a significant increase $(p<.01)$ in length was obtained (Table 1$)$. The ability to demonstrate significant length changes more readily than weight changes probably is due to the lower precision of weight measurements, due to some variation in water and food content of the animals when measured.

When the tadpoles in this experiment were staged after 2 and 3 weeks of treatment, animals receiving 5 and $50 \mu \mathrm{g}$ of prolactin were found to be metamorphosing more slowly than the controls. The initial metamorphic stages in all groups ranged between XII and XIV. The prolactin-treated groups advaneed to stages XVI-XVII during the first week or two of treatment, after which they remained stationary, whereas the control and GH-treated animals continued to advance to metamorphic climax. The anti-metamorphic effect of prolactin is also shown by its effect in suppressing hind leg growth (Table 2). Doses of prolactin below $5 \mu \mathrm{g} /$ day did not affect the rate of metamorphosis.

The effectiveness of doses of prolactin of $5 \mu \mathrm{g} /$ day or greater in retarding meta morphosis was confirmed in two other experiments, with 5,10 and $25 \mu \mathrm{g} / \mathrm{day}$ for 2 -week periods. However, one interesting

\section{TABLE 2}

Hind Leg liength Changes in Control and Prolactin-Treated Tadpoles Betwern Days 11 and 17 of Treatment

\begin{tabular}{llcc}
\hline & & & Length ehange \\
Group & Treatment & $n$ & Mean $\pm \$ D(\mathrm{~min})$ \\
FG & Saline & 10 & $1.37 \pm .36$ \\
F & Prolactin & 27 & $0.58 \pm .12 a$
\end{tabular}

${ }^{a}$ Significantly different from controls $(p<.025)$. 
exceptional response suggests that the effectiveness of prolactin in blocking metamorphosis is related to the stage of metamorphosis at the time of initiation of treatment: In this case, $10 \mu \mathrm{g} /$ day failed to retard metamorphosis in animals of initial stage IX-X. In the experiments in which retardation occurred, the initial stage of the animals was XII-XIV.

\section{Effects of Combined Prolactin and Thyroxine Treatment on Metamorphosis}

Since one of the actions of the prolactin administered to tadpoles is clearly an inhibition of the rate of metamorphosis, the question of the level at which prolactin is acting is raised. One possibility is that prolactin renders the peripheral tissues insensitive to thyroid hormone, either partially or completely. To test this hypothesis tadpoles were injected with prolactin until their metamorphic rate had been severely reduced and then exogenous thyroxine was administered. Prolactin treatment continued during thyroxine administration. One would expect no metamorphic response to thyroxine if the tissues become insensitive or a reduced response if the tissues are less sensitive. Tadpoles were injected daily with prolactin for an 18-day period. Two weeks after prolactin treatment began, part of both the prolactin-treated and control groups were put in a $100 \mu \mathrm{g} /$ liter thyroxine solution (Fig. 2). Both prolactin-treated and control tadpoles began to metamorphose within a 3-day period in response to the thyroxine. Because of the relatively large thyroxine dose however, it was not possible to determine whether or not the tadpoles had a reduced thyroxine sensitivity but it was clear that they had not become completely insensitive to thyroxine.

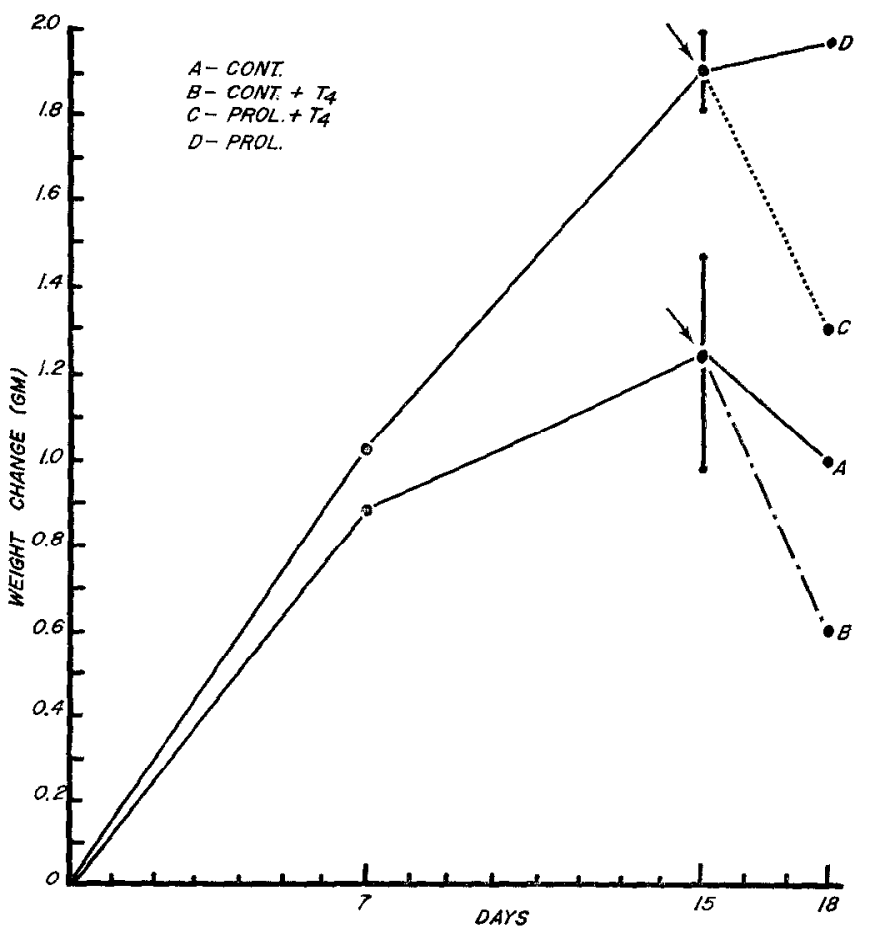

FIa. 2. Weight changes in tadpoles in an 18-day period. Group $A B$ was treated with daily saline injections and group $C D$ with $5 \mu \mathrm{g} /$ day prolactin. At Day 15 groups $A B$ and $C D$ were divided into $A$ and $B$, and $C$. and $\mathrm{D}$, respectively. Both $\mathrm{C}$ and $\mathrm{D}$ continued to receive $5 \mu \mathrm{g} /$ day prolactin. Groups $\mathrm{B}$ and $\mathrm{C}$ were kept in. $100 \mu \mathrm{g} /$ liter thyroxine solution from days 15-18. Arrows indicate the initiation of thyroxine treatment. Vertical lines at Day 15 represent standard errors of the mean weight changes from Day 0 . Number of animals per group: $\mathrm{A}=6 ; \mathrm{B}=8 ; \mathrm{C}=12 ; \mathrm{D}=12$. 
A second similar experiment was done but lower doses of thyroxine were used. The prolactin treated tadpoles (group FG) received $10 \mu \mathrm{g} /$ day of bovine prolactin. At Day 17 the prolactin dose was increased to $25 \mu \mathrm{g} /$ day and kept there for the rest of the 29-day period. See Figs. 3 and 4 for details of thyroxine treatment.

Body weight, body length and hind leg length were measured and the metamorphic stages noted at Days $0,6,11,17,24,27$, and 29. Body weight changes essentially paralleled length changes so only length data are shown here (Fig. 3). By Day 17, before thyroxine treatment was initiated, prolactin had already promoted significant increases in length and weight $(p<.001)$, and suppression of metamorphosis as reflected by reduced hind limb growth $(p<.025)$ (Table 2). Between Days 17 and 24, $4 \mu \mathrm{g}$ of thyroxine did not affect weight in either prolactin (group G) or nonprolactin (group D) groups. A thyroxine dose of $10 \mu \mathrm{g}$ /liter caused a slight reduction in length and weight betwecn Days 24 and 27 , an cffect which was accelerated when the dose was increased to $75 \mu \mathrm{g} /$ liter between Days 27 and 29. All doses of thyroxine were adequate to accelerate hind limb growth significantly. Apparently hind leg growth is more sensitive to low thyroxine doses than are weight and length. The most important feature of these results is that there was no apparent difference in thyroxine sensitivity, by any of these criteria and at all doses used, between the prolactin-treated and the nonprolactin-treated tadpoles.

\section{Effects of Reduced Thyroid Activity on Growth Promotion by Prolactin}

Because of the possibility that the growthpromoting effects of prolactin might be secondary to the metamorphosis-inhibiting effect of the hormone (see introduction), it was important to determine if proluctin would stimulate growth beyond that caused

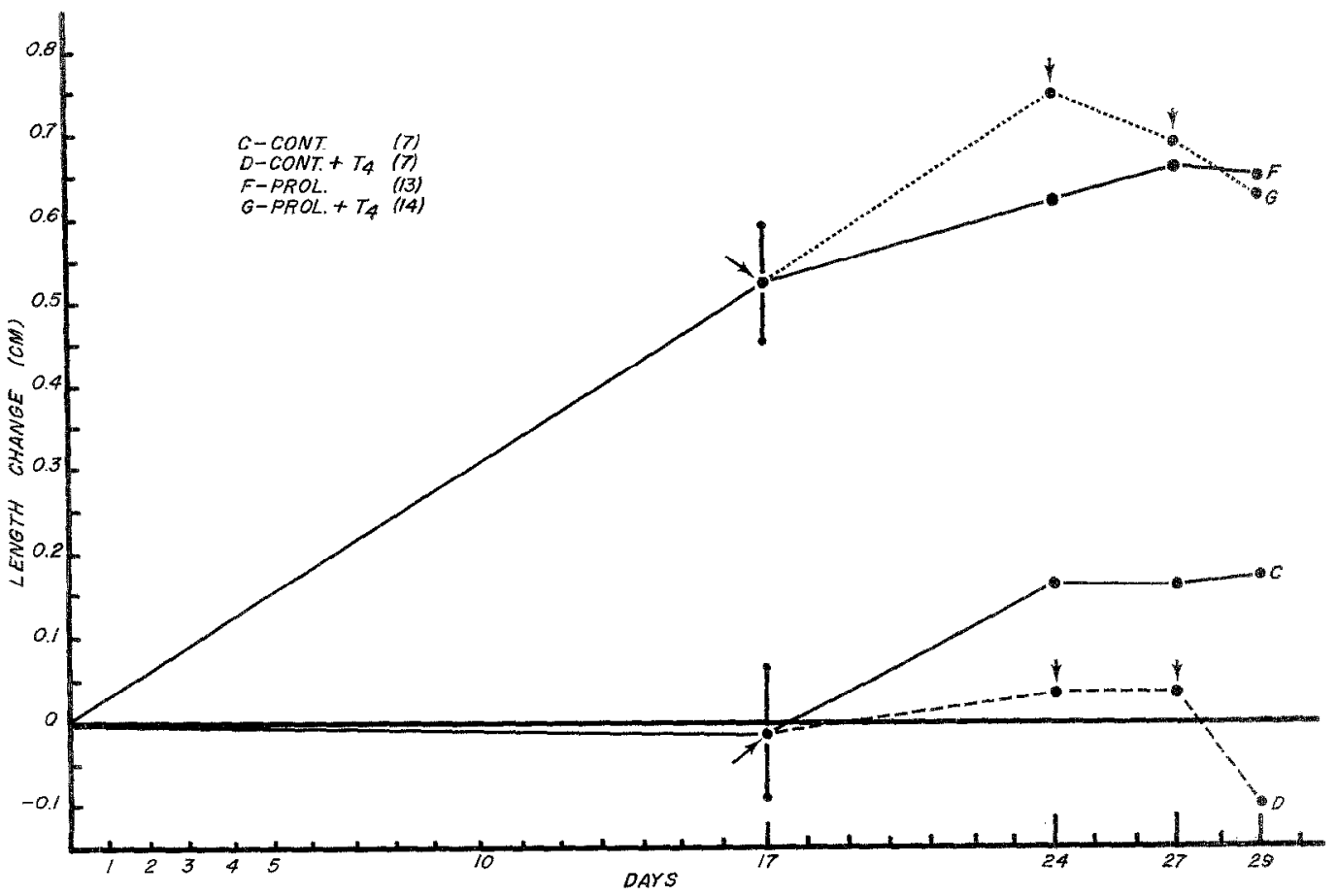

FrG. 3. Mean length changes in tadpoles injected with saline (CD) and prolactin (FG) for 29 days. Groups CD and FG were both divided at Day 17 and D and $G$ were then kept in a $4 \mu \mathrm{g} /$ liter thyroxine solution. Tle thyroxine dose was increased to $10 \mu \mathrm{g}$ /liter on Day 24 and to $75 \mu \mathrm{g} / \mathrm{hiter}$ on Day 27 . Arrows indicate initiation of thyroxine treatment and dose changes. Standard errors of the mean length changes from Day 0 are indicated by vertical lines at Day 17 . Numbers in parentheses indicate number of animals per grour. 


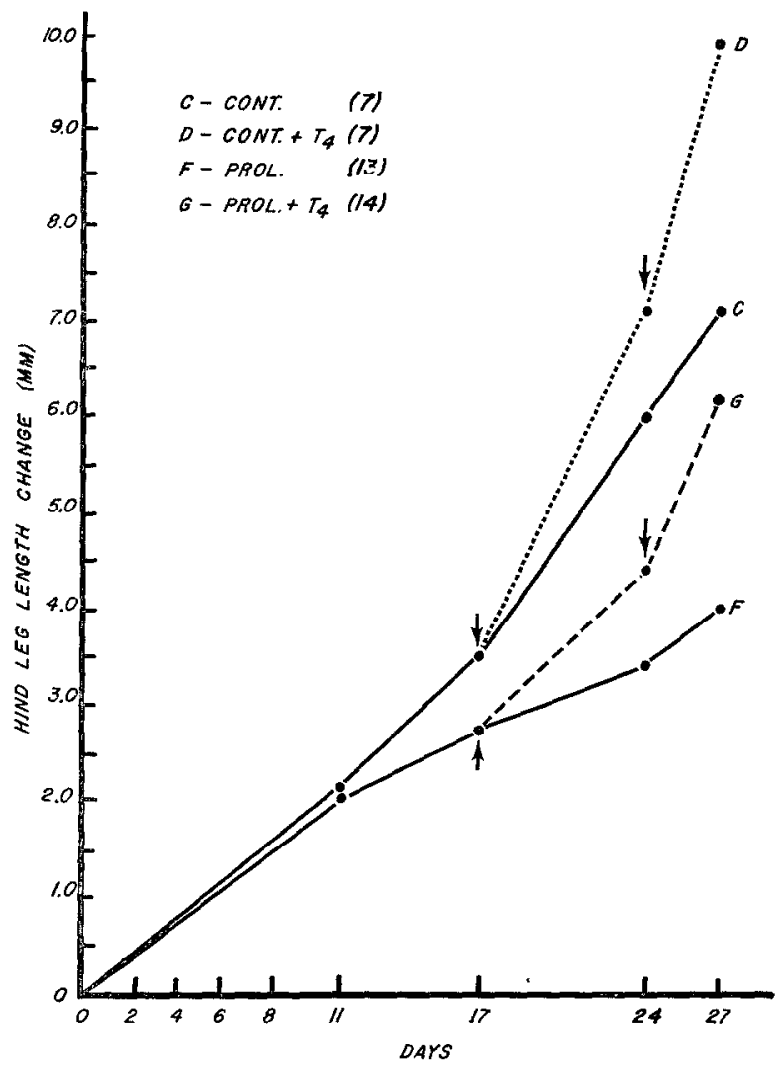

FIg. 4. Mean hind leg length changes in tadpoles injected with saline (CD) and prolactin (FG) for 27 days. Groups CD and FG were divided at Day 17 and $D$ and $G$ were then kept in $4 \mu \mathrm{g} /$ liter thyroxine solution. On Day 27 the thyroxine dose was increased to $10 \mu \mathrm{g} /$ /iter. Arrows indicate initiation of thyroxine treatment and dose change. Numbers in parentheses indicate number of animals per group.

by thyroidal suppression alone. This problem has been examined by analysis of the growth promoting activity of prolactin in tadpoles rendered hypothyroid by a thyroid inhibitor (thiouracil) or by thyroidectomy.

Tadpoles were kept in a $0.05 \%$ thiouracil solution, a dose which effectively inhibited metamorphosis. After 11 days of thiouracil treatment the tadpoles were divided into three groups. Group C was removed from the thiouracil; groups A and B were kept in thiouracil for another 2 weeks, during which group $\Lambda$ recoivod daily injections of saline, and group $\mathrm{B}$ received $10 \mu \mathrm{g}$ /day bovine prolactin. Weight and length changes were recorded for the 2 weeks of saline or hormone treatment, corresponding to days 11-26 of thiouracil treatment. Thiouracil treatment alone resulted in an increase in size of tadpoles over those removed from thiouracil after 11 days, indicating that inhibition of thyroid activity results in al increase in growth rate, as expected. Prolactin treatment combined with thiouracil resulted in a significant further increase in size over thiouracil alone (weight change, $p<.025$; length change, $p<.05$ ). This effect is illustrated in Fig. 5. After removal from thiouracil, group $\mathrm{C}$ animals resumed metamorphosis, and decreased in size.

Two similar experiments were done, utilizing thyroidectomized tadpoles instead of thiouracil-treated tadpolcs. Tadpoles were thyroidectomized or sham thyroidectomized, in one experiment, one week prior to hormone treatment. Treatment of tadpoles consisted of the following:

Group A-

sham thyroidectomy, daily saline injections 

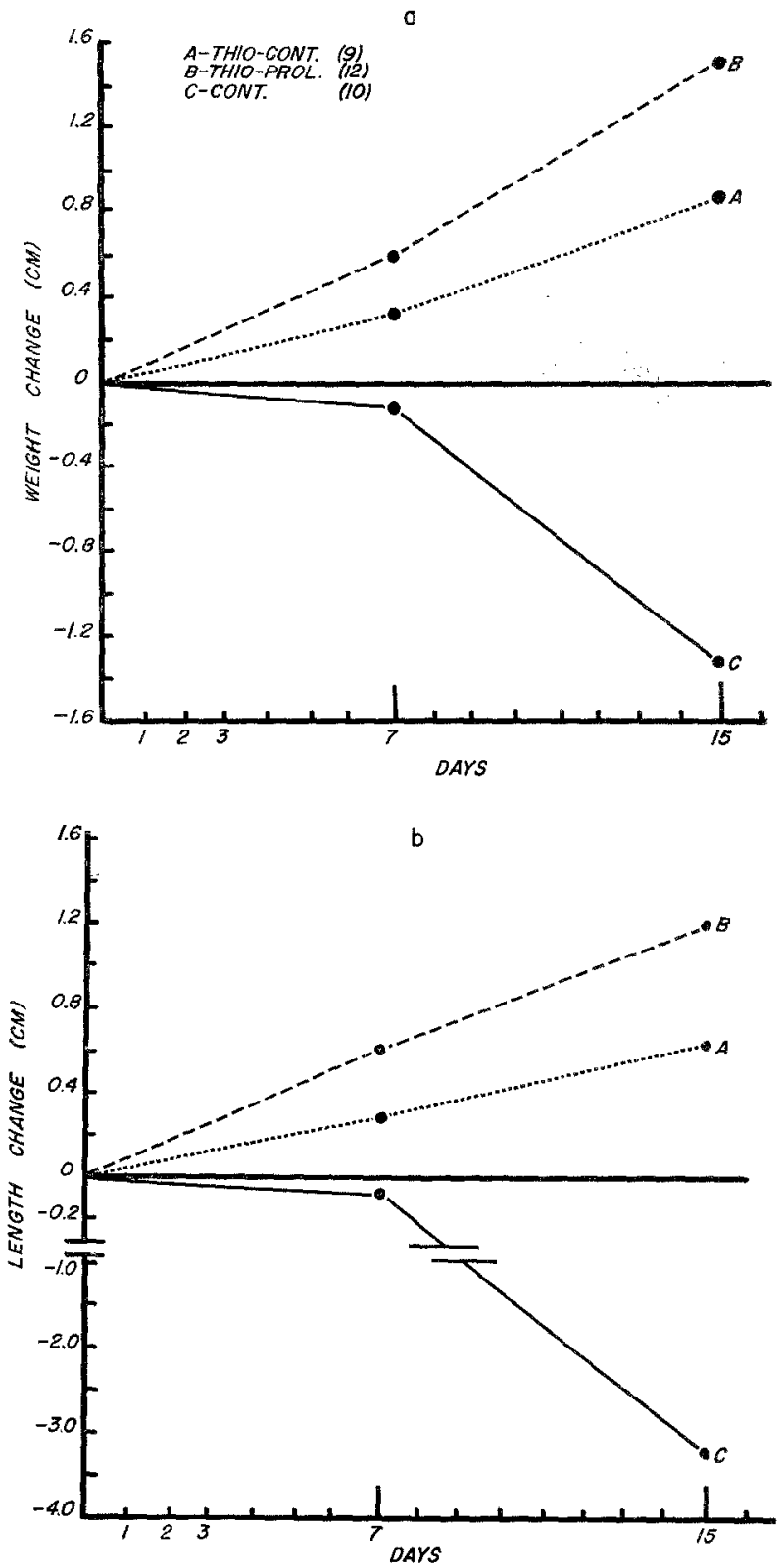

FiG. 5. Mean weight and length changes in R. pipiens tadpoles treated with thiouracil (A); thiouracil and $10 \mu \mathrm{g} /$ day prolactin (B); and no thiouracil or prolactin treatment (C) during a 15-day period. Numbers in parentheses indicate number of animals per group. Standard errors at Day 15: weight-A $= \pm 0.14, \mathrm{~B}=$ $\pm 0.09, \mathrm{C}= \pm 0.20$; length- $\mathrm{A}= \pm 0.06, \mathrm{~B}= \pm 0.08, \mathrm{C}= \pm 0.57$.

Group B-

\section{Group C-.}

thyroidectomy, daily saline injections

thyroidectomy, $5 \mu \mathrm{g} /$ day bovine prolactin Group D-

thyroidectomy, $15 \mu \mathrm{g} /$ day bovine prolactin
The weight and length-changes for one these experiments for the 2 -week period are shown in Fig. 6. There was no significant difference between the length changes in the two control groups (A and B). Both prolactin groups (C and D) responded with an 

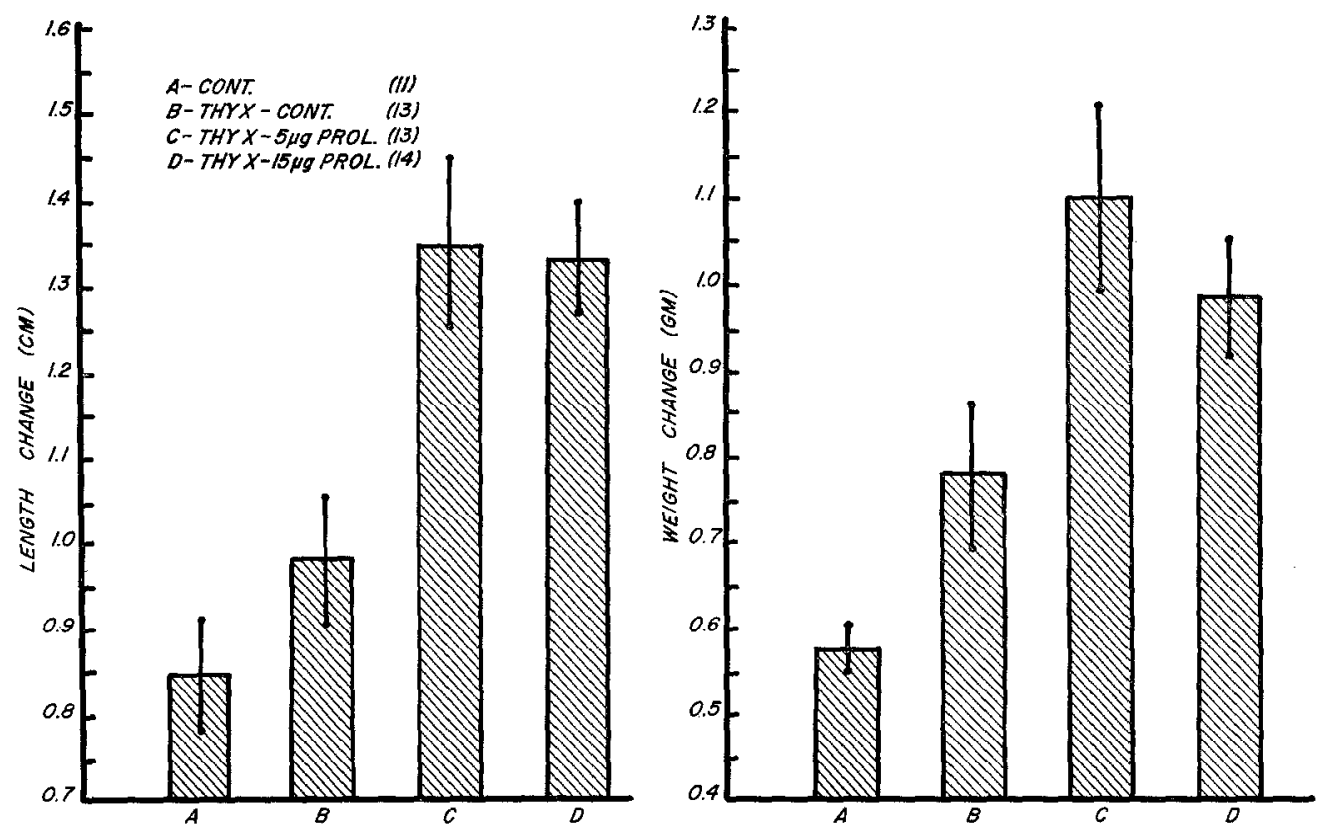

FIG. 6. Mean weight and length changes \pm standard error in $R$. pipiens tadpoles treated with saline (A and B), $5 \mu \mathrm{g} /$ day prolactin (C) or $15 \mu \mathrm{g} /$ day prolactin (D). Groups B, C, and D were thyroidectomized. Weight and length changes are for a 2 -week period. Numbers in parentheses indicate number of animals per group.

increased length compared to $\mathrm{B}(p<.02, \mathrm{C}$; $p<.01, \mathrm{D})$. Thyroidectomized animals increased in weight compared to sham operated controls $(p<.05)$. Although the mean weight changes in prolactin-treated thyroidectomized animals were greater than in thyroidectomized animals, the difference was significant $(p<.05)$ only at the lower prolactin dose. Statistically, the response of the higher prolactin dose animals was not different from either the $5-\mu \mathrm{g}$ dose, or the saline controls. The acceleration of growth after thyroidectomy, as well as the growth response of prolactin-treated thyroidectomized animals was not so dramatic as in the comparable thiouracil-treated groups. Feeling that this might be due to incomplete thyroidectomy and metamorphic arrest in some animals, the experiments were repeated using only thyroidectomized animals which were arrested in metamorphosis before being put into the experiment. The results were similar to those presented above. A $10 \mu \mathrm{g} /$ day prolactin dose promoted an increase in length and weight in thyroidectomized tadpoles compared to saline-treated thyroidectomized tadpoles $(p<.001)$.

\section{DISCUSSION}

\section{Prolactin and Growth Hormone Stimulation of Tadpole Growth}

This report confirms a number of recent studies which have shown that tadpoles injected with mammalian prolactin preparations grow abnormally large. Publications include those of Berman et al. (1964) and Bern et al. (1967) with Rana catesbeiana, Etkin and Gona (1967) with $R$. pipiens, and Rémy and Bounhiol $(1965,1966)$ with the toad Alytes ohstetricans. Although the species differed, our results and those of Berman et al. (1964) and Bern et al. (1967) suggest that a minimum effective dose of prolactin that will produce an increase in tadpole length is $0.5-1.0 \mu \mathrm{g} /$ day for 1 or 2 wee'ss (approximately 0.01-0.02 IU/day).

Although the increase in length indicates that the growth which prolactin promotes is not simply an uptake of water, the dry 
weight data is further support for this sonclusion. Rémy and Bounhiol (1966) have found that in a few toads that metamorphosed successfully, the prolactintreated toads were larger than conlrols. In addition to the length and wet weight data that is recorded in most studies, the dry weight data reported here and the increased size after metamorphosis reported by Rémy and Bounhiol (1966) indicate that a prolactin-like hormone may indeed by playing an important physiological role in controlling size in amphibia.

The effect of $\mathrm{GH}$ on growth in tadpoles is not as clear cut as the prolactin effect, and definite stimulation is obtained only when relatively high doses of $\mathrm{GH}$ are used. Etkin and Gona (1967) reported stimulation of weight gain in tadpoles after treatment for 3-4 weeks with GH. The report of Berman et al. (1964) of growth promotion by $\mathrm{GH}$ proved to be in error as the hormone preparation was mislabeled prolactin. Bern et al. (1967) reported an increase in size of GII-treated tadpoles in some experiments. We found that $50 \mu \mathrm{g} /$ day was the lowest GH dose that produced a significant increase in length in $R$. pipiens tadpoles treated for a 2 -week period. The increase in size with this dose of GH was less than in tadpoles treated with a smaller dose $(10 \mu \mathrm{g} / \mathrm{day})$ of prolactin. Thus the effective dose appears to be around $50 \mu \mathrm{g}(0.05-0.08$ USP units) of $\mathrm{GH}$ per day. Although direct comparisons are not possible, because of inexact information on molecular weight and purity of the hormones used, our data suggest that in the growth response, tadpoles are 25-50 times less sensitive to $\mathrm{GH}$ than to prolactin.

The NIH bovine growth hormone preparation used in our experiments was assayed (by NIH) for contamination by other pituitary hormones. From this information the maximum possible prolactin contamination of the GH was ealculated to be approximately $0.02 \mathrm{IU} / 50 \mu \mathrm{g}$. Since this is the order of the minimum effective prolactin dose mentioned above, the growth response of tadpoles to our $\mathrm{GH}$ preparation could possibly be due to contaminating prolactin. The same reservation presumably applies to the growth stimulating effects reported for GH preparations by other workers. Thus, it appears that only prolactin has unequivocally been shown to promote growth in tadpoles.

\section{Prolactin Effects on Metamorphosis}

Prolactin doses of 5,25 , and $50 \mu \mathrm{g} / \mathrm{day}$ retarded metamorphosis, as determined by metamorphic stages and from retardation of hind limb growth. Etkin and Gona (1967) also reported a decrease in hind leg growth (after an initial increase) as well as tail resorption in prolactin-treated tadpoles. Nicoll et al. (1965) however, reported no change in hind leg growth in $R$. catesheiana tadpoles in 1- and 2-week periods of treatment with 5 or $10 \mu \mathrm{g}$ of prolactin. In our experiments metamorphosis was not noticeably retarded with doses of 0.5 and $1.0 \mu \mathrm{g} /$ day. Thus, it appears that doses of $5 \mu \mathrm{g} /$ day or more are necessary to interfere with metamorphosis in $R$. pipiens, and that metamorphosis is less sensitive than growth to prolactin.

The exceptional experiment in which prolactin failed to inhibit development of tadpoles younger than stage XIT-XIV is of particular interest. Since it has been shown that tadpoles thyroidectomized or treated. with thyroid inhibitors progress to stage XII-XIV before metamorphosis is arrested. (Hanaoka, 1966; Smith and Smith, 1923; Steinmetz, 1952, 1954), it appears that tadpoles must have entered the thyroiddependent stages of development in order for prolactin inhibition to be effective.

Although it is clear that prolactin blocks metamorphosis in some way, conflicting opinions have been published concerning the level at which the block occurs. Gona (1967, 1968) has presented evidence that prolactin interferes with the secretion of thyroid hormone by the thyroid gland. Bern et al. (1967) found that prolactin countered the effect of thyroxine on reducing tail size but that it did not counter the thyroxine eflect of increased hind leg growth. In our experiments, which were similar in design to those of Bern et al. (1967), prolactin did not noticeably alter 
the hind leg growth, body weight or length response of tadpoles treated with doses of thyroxine ranging from near minimal effective levels to strongly stimulatory doses (4-100 $\mu \mathrm{g} /$ liter) compared to the responses of equivalent control animals. Thus our data do not show that prolactin acts to make the tissues insensitive to thyroxine. The counteraction of prolactin and thyroxine on tail size shown by Bern et al. (1967) may be due to a greater quantity of prolactin reaching the tail region since their injection site of pituitary hormones was the tail. Derby and Etkin (1968) have recently shown that pituitary hormones inhibit thyroxine-induced reabsorption of isolated pieces of tail fin in vitro. Thus, under certain circumstances it is possible to demonstrate an antimetamorphic effect of prolactin through both an antithyroid action and an effect on peripheral tissues.

\section{Interrelationship of Growth and Metamorphic Effects}

Considering the two effects that prolactin has on tadpoles: (1) Increasing size and (2) decreasing the rate of metamorphosis, the question arises as to whether the two effects are separable or whether one is a result of the other. If one effect is a direct result of the other, one possible hypothesis is that tadpole growth is controlled by the absolute level of thyroid hormone. In this case prolactin would act to lower the effective thyroid hormone level and this in itself would promote growth. If the effects are separate, then while prolactin is interfering with metamorphosis, it is also acting independently to cause growth. Our results indicate that prolactin causes an increase in size of tadpoles beyond that which occurs when the level of thyroid hormone is decreased by thyroidectomy or thiouracil treatment. This further growth stimulation in animals in which the thyroid is already maximally inhibited indicates that the prolactin action on growth may indeed be separable from its action on the thyroid. Consequently, a direct effect of prolactin on the peripheral tissues rather than one modiated only by interference with the thyroid is the more likely alternative.
However, it remains possible that the prolactin inhibition of the thyroid facilitates the growth-promoting action of prolactin, since prolactin cannot stimulate growth when the thyroid hormone level is high.

It has been well documented that depression of thyroid hormone level in tadpoles leads to an increase in size (Allen, 1918, 1925; Hoskins and Hoskins, 1919; Steinmetz, $1952,1954)$. However, it is not clear whether the decrease in the level of thyroid hormone is the direct cause of the increase in size, or whether depression of thyroid hormone level allows a greater secretion or more effective level of activity of a pituitary growth factor. The possibility of this kind of relationship between the pituitary and the thyroid in the regulation of growth has been suggested earlier by Steinmetz (1954).

\section{General Discussion and Conclusions}

The results contained in this report and in the various papers cited above clearly support the inference that the pituitary gland of tadpoles produces at least one factor necessary for normal growth. The various effects obtained with exogenous prolactin support the hypothesis of Etkin and Gona (1967) and Bern et al. (1967) that normal growth and development of tadpoles is regulated by a balance between a prolactin-like hormone and thyroid hormone, favoring larval growth on the one hand, and metamorphosis on the other. Substantiation of these ideas requires the demonstration of a growth-stimulatingmetamorphosis-inhibiting factor in the pituitary gland of tadpoles, and information on the normal levels and secretion rates of such a native hormone during development.

From the biochemical point of view, the inference that the tadpole growth factor is "prolactin-like" is perhaps unsound, and comparative data on the biochemistry and biological activities of prolactin and the tadpole growth factor are essential. Several bioassays of adult amphibian pituitary have demonstrated the presence of pigeon crop stimulating activity (Foglia, 1940; Nicoll and Bern, 1965) and mammotropic activity (Chadwick, 1966a, 1966b; Nicoll et al., 1966) in amphibians, but no similar assays 
of tadpole pituitaries have been done. Nlthough the task would bo formidable recause of the minute size of the tadpole pituitary, this kind of approach would appear to be the next step necessary to further expand our understanding of the nature of growth regulation in amphibian larvae.

An interesting new aspect of the problem of growth regulation in amphibians has developed in a study parallel to the present report, in which we have found that in postmetamorphic frogs, mammalian growth hormone is relatively a much stronger growth promoting agent than prolactin (Brown and Frye, 1969). This difference in the growth responses of tadpoles and frogs to prolactin and $\mathrm{GH}$ suggest that the primary mechanism of growth control may be different in these two stages of the life cycle.

\section{REFERENCES}

Aluex, B. M. (1916). The results of extirpation of the anterior lobe of the hypophysis and of the thyroid of Rana pipiens larvae. Science 44, $755-757$.

Aluen, B. M. (1918). The results of thyroid removal in the larvae of Rana pipiens. J. Exptl. Zool. 24, 499-519.

Allen, B. M. (1925). The effects of extirpation of the thyroid and pituitary glands upon the limb development of anurans. J. Exptl. Zool. 42, $13-30$.

Berman, R. H., Bern, H. A., Nicoll, C. S., atd SrroHMAN, R. C. (1964). Growth promoting effects of mammalian prolactin and growth hormone in tadpoles of Rana catesbeiana. J. Exptl. Zool. 156, 353-360.

Bern, H. A., Nicoll, C. S., and Strohman, R, C. (1967). Prolactin and tadpole growth. Proc. Soc. Exptt. Biol. Med. 126, 518-520.

Bounhiol, J. J., Drsclos, G., and Disclos, P. (1959). Influence de l'hormone somatotrope sur la croissance du crapaud accoucheur. Ass. Anat. XIVT Reunion, 118-123.

Brown, P. S., ANd Frye, B. F. (1969). Effects of hypophysectomy, prolactin and growth hormone on growth of postmetamorphic frogs. Gen. Comp. Endocrinol. (In press).

Chaowick, A. (1966a), Prolactin-like activity in the pituitary gland of the frog. J. Endocrinal. 34, 247-255.

CrADWICK, A. (1966b). Prolactin-like activity in the pituitary gland of fishes and amphibians. $J$. Endocrinol. 35, 75-81.

Dent, J. N. (1959). A technique for removing thyroid glands from anuran larvae. Endocrim nology $64,314-316$.

Derby, A., AND ETkin, W. (1968). Thyroxine induced tail resorption in vitro as affected by anterior pituitary hormones. J. Exptl. Zool. 169, 1-8.

Etkin, W. (1964). Metamorphosis. In "Physiology of the Amphibia" (J. A. Moore, ed.), pp. 427-468. Academic Press, New York.

EtKin, W., ANd Gona, A. G. (1967). Antagonism between prolactin and thyroid hormone in amphibian development. $J$. Expll. Zool. 165, 249268.

Eitkin, W . AND Lehren, R. (1960). Excess growth in tadpoles after transplantation of the adcnohypophysis. Endocrinology 67, 457-466.

Everetr, J. W. (1966). The Control of the Secretion of Prolactin. In "The Pituitary Gland" ( $\mathrm{C}$. W. Harris and B. I. Donovan, eds.), Vol, 2, 106194. University of California Press, Berkeley.

Fogtia, V. G. (1940). Acción de la hipófisis del sapo Bufo arenarum Hensel sobre el buche de la paloma. Rev. Soc. Argent. Biol. 16, 559-562.

Gona, A. G. (1967). Prolactin as a goitrogenic agent in Amphibia. Endocrinology 81, 748-754.

Gona, A. G. (1968). Radioiodine studies on the metamorphosis inhibiting effect of prolactin on tadpoles. Arat. Rec. 160, 355.

Hanaoka, X. (1966). The effect of thyroxine on the metamorphosis in hypophysectomized and thyroidectomized frog tadpoles (Rana ornativentis), J. Fac. Sci. Hokkaido Univ. (Zool.) 16, 98-105.

IIoskins, E. R., ANd Hosknns, M. M. (1919). Growth and development of amphibic as affected by thyroidectomy. J. Exptl. Zool. 29, 149.

Nicoll, C. S., ANd BerN, H. A. (1965). Pigeon crop-stimulating activity (prolactin) in the adenohypophysis of lungfish and tetrapods. Endocrinology 76, 156-160.

Nicoli, C. S, Bers, H. A., Dunlop, D., ANo StroHMaN, R. C. (1965). Prolactin, growth hormone, thyroxine and growth of tadpoles of Rana catesbiana. Am. Zool. 5, 739.

Nrcoll, C. S., Bers; H. A., AND Brown, D. (1966). Occurrence of mammotrophic astivity (prolartin) in the vertebrate adenohypophysis. J. Endocrinol. 34, 343-354.

RÉmY, C. (1964). L'hormone somatotrope provoque le gigantisme chez le têtard d'Alytes obstetricans (Laur) hypophysectomisé. Comptes Rend. Acad. Sci. 259, 1233-1236.

Rémy, C., and Botnhrol, J. J. (1965). Croissance 
exagérée des têtards de crapaud accoucheur entiers ou privés de leur hypophyse, et subissant un traitment par la prolactine. Comptes Rend. Soc. Biol. (Paris) 159, 1532-1535.

RÉmy, C., AND Bounhiol, J. J. (1966). Gigantisme expérimental obtenu par intervention chirurgicale et traitements hormonaux chez le têtard du crapaud accoucheur. Ann. Endocrinol. (Paris) Suppl. 27, 377-382.

Sмrrн, P. E. (1916). The effect of hypophysectomy in the early embryo upon growth and development of the frog. Anat. Rec. 2, 57-64.

Smith, P. E., and Smith, I. P. (1923). The function of the lobes of the hypophysis as indicated by replacement therapy with different portions of the ox gland. Endocrinology 7, 579591.

Steinmetz, C. H. (1952). Thyroid function as related to the growth of tadpoles before metamorphosis. Endocrinology 51, 154-156.

STEINMETz, C. H. (1954). Some effects of thyroxine and antithyroid compounds on tadpoles and their relation to hormonal control of growth. Physiol. Zool. 27, 28-40.

Taylor, A. C., and Kollros, J. J. (1946). Stages in the normal development of Rana pipiens larvae. Anat. Rec. 94, 7-24.

Wright, P. A., ANd Flathers, A. R. (1961). Facilitation of pituitary induced ovulation by progesterone in early fall. Proc. Soc. Exptl. Biol. Med. 106, 346-347. 